\title{
Freezability and Fertility Results with Uncentrifuged Stallion Semen
}

\author{
By M.-L. Heiskanen ${ }^{1}$, L. Hilden ${ }^{2}$, S. Hyyppä ${ }^{2}$ A. Kangasniemi ${ }^{2}$, A. Pirhonen ${ }^{1}$ and P. H. Mäenpää
}

'Department of Biochemistry \& Biotechnology, University of Kuopio, and ${ }^{2}$ Equine Research Station, Agricultural Research Centre, Ypäjä Finland.

\begin{abstract}
Heiskanen, M.-L., L. Hilden, S. Hyyppä, A. Kangasniemi, A. Pirhonen, and P. H. Mäenpää: Freezability and fertility results with uncentrifuged stallion semen. Acta vet. scand. 1994, 35, 377-382. - The first (1 to 3) sperm-rich fractions of the ejaculate were collected from 4 stallions using an open-ended vagina. The volume of the collected fractions was $12 \pm 8 \mathrm{ml}$ with a density of $475 \pm 200$ million spermatozoa/ml. Before freezing, the semen was diluted with a skim-milk based extender $1: 1$ to $1: 8$ (volume of semen : volume of extender), depending on the initial sperm concentration to achieve a final concentration of $100 \mathrm{million} / \mathrm{ml}$. The total number of spermatozoa in an insemination dose ranged from 0.7 to 1 billion spermatozoa. Within $12 \mathrm{~h}$ after ovulation, 48 mares were inseminated in 70 cycles. The total single-cycle pregnancy rate at day 21 was $24 \%$, but varied from $10 \%$ to $33 \%$ per cycle among the stallions.
\end{abstract}

\section{equine; frozen semen; seminal plasma.}

\section{Introduction}

Per cycle pregnancy rates with frozen sperm usually vary between $30 \%$ and $70 \%$ (Cristanelli et al. 1984, Volkmann \& van Zyl 1987, Anon. 1991, Darenius \& Darenius 1992). However, with a high percentage of stallions, the pregnancy rates per cycle are between $20 \%$ and $40 \%$ (Brinsko \& Varner 1992), which is less than half of that obtained in inseminations with fresh semen done close to ovulation (Koskinen et al. 1990, Woods et al. 1990). In commercial breeding programs with frozen sperm, satisfactory results have often been achieved using only stallions selected on the basis of their sperm freezability and with mares selected on the basis of their high fertility.

Spermatozoa of animal species having dense sperm and small volume of seminal fluid (e. g., ruminants) freeze better than sperm of stallions and swine, which have less concentrated sperm. When stallion semen is collected with a closed artificial vagina, or when high concentration of sperm is required in freezing, centrifugation is a desirable method to concentrate sperm prior to freezing (Pickett et al. 1975, Martin et al. 1979). Cochran et al. (1984) have shown that centrifugation decreases the motility of spermatozoa suggesting that tight packaging of the cells is probably detrimental to either the cellular structures or the metabolism of the sperm cells. Since there are contradictory results with respect to the effects of centrifugation on freezability (Pickett et al. 1975, Cochran et al. 1984), centrifugation was omitted in this study. The post-thaw motility is also affected by the dilution ratio and the concentration of the remaining seminal plasma (Pickett et al. 1975, Jasko et al. 1991, Bittmar et al. 1992). The aim of this study was to examine freezability and subsequent fertility of uncentrifuged semen extended with a skim-milk extender in different ratios. 
Table 1. Composition of the freezing extender (Equi-Techning, personal communication, 1990).

\begin{tabular}{lc}
\hline a) Solution of salts and sugars & \\
& \\
Glucose $(\mathrm{g})$ & 25.0 \\
Lactose $(\mathrm{g})$ & 1.5 \\
Raffinose (g) & 1.5 \\
Sodium citrate dihydrate (g) & 0.3 \\
Potassium citrate (g) & 0.41 \\
Hepes (g) & 7.14 \\
Egg yolk (ml) & 20 \\
Streptomycin (mg) & 50 \\
Penicillin (IU) & 50,000 \\
\hline
\end{tabular}

Diluted up to $500 \mathrm{ml}$ with deionized water.

b) Skim milk (ml) 500.0

$50 \mathrm{~g}$ nonfat dried milk powder diluted in $500 \mathrm{ml}$ of deionized water.

Solutions a and $\mathrm{b}$ were mixed and glycerol was added to a final concentration of $2.5 \%$.

\section{Materials and methods}

Semen collection and freezing

Semen was collected from 4 stallions of different breeds with seasonal pregnancy rates of $60-85 \%$ achieved using artificial insemination or natural breeding. One to 3 first sperm-rich jets were collected with an open-ended vagina. After collection and density evaluation of 6 ejaculates from Finnhorse A, 4 from Finnhorse B, 4 from warmblooded riding horse C, and 5 from Standardbred stallion D, the semen was diluted without centrifugation with skim-milk based extender (Table 1) in plastic bags. The dilution ratios were from 1 : 1 to $1: 8$ (volume of semen : volume of extender) depending on the initial sperm density to achieve a final concentration of 100 million $/ \mathrm{ml}$. The air was removed, and the bag was precooled in a refrigerator $\left(5-7^{\circ} \mathrm{C}\right)$ for $30 \mathrm{~min}$. Glycerol was added in $5 \mathrm{ml}$ quantities to a final concentration of $2.5 \%$, and the cooling was prolonged for additional $30 \mathrm{~min}$. The ex- tended semen was packaged in 2.5-ml plastic straws (Minitüb, Landshut, Germany). The filled straws were frozen on a metal rack lowered into a styrofoam box to a position about $3 \mathrm{~cm}$ above liquid nitrogen. Ten min later they were plunged into liquid nitrogen. After a 1 to 51-day storage in liquid nitrogen (6 doses were used later after a 3-year storage), the straws were thawed in a $50^{\circ} \mathrm{C}$ water bath for $40 \mathrm{~s}$. The motility was evaluated microscopically in a Makler chamber before and after freezing. After thawing, the semen was warmed in a $37^{\circ} \mathrm{C}$ water bath for $10 \mathrm{~min}$ before evaluation of motility. The total volume of an insemination dose varied from 7 to $9 \mathrm{ml}$ containing 700-1000 x $10^{6}$ spermatozoa, over 250 million of which were progressively motile.

\section{Mares and timing of inseminations}

During the breeding season of 1990,3 to 16 year-old mares (27 Finnhorses, 9 standardbreds, and 12 warmblooded riding-horse mares) were inseminated in 64 cycles. In 1993, the inseminations were supplemented with 6 cycles. Follicular status was monitored by palpation and ultrasound every other day until a $35 \mathrm{~mm}$ diameter follicle was detected and, thereafter, every $12 \mathrm{~h}$ until ovulation occurred. The mares were inseminated within 12 $h$ after the ovulation. The pregnancy status of the mares was examined 15 to 21 days after the ovulation.

\section{Statistical analysis}

Semen volumes, concentrations, motilities, and dilution ratios are shown as arithmetic means and standard deviations (s.d.). Fisher's exact test in a single $2 \times 4$ table and $2 \times 2$ tables (Conover 1980) was used to asses the statistical significance between the pregnancy rates of different stallions. 

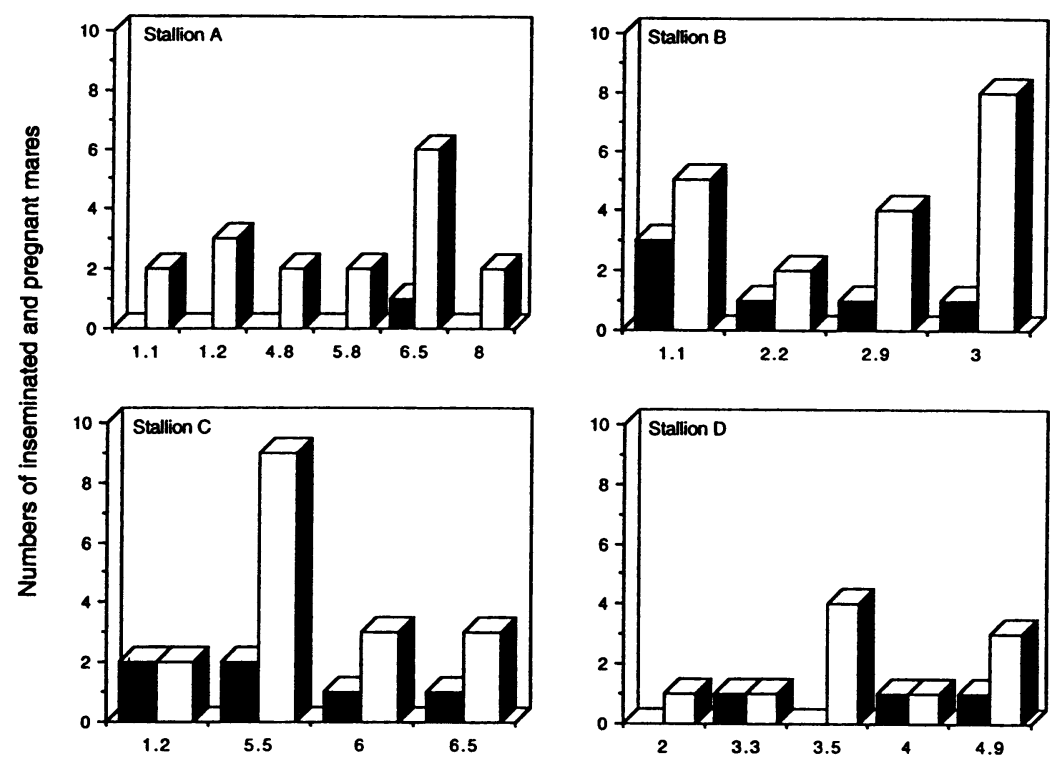

Volume of extender to volume of semen

Figure 1. Pregnancy rates with the extended ejaculates from stallions A, B, C and D. The volume of the extender added to one volume of semen in each ejaculate is shown for each stallion with numbers of pregnant mares ( $\square)$ and numbers of inseminated cycles ( $\square$ ).

\section{Results}

The total volume of the sperm-rich jets (1 to 3) collected was $12 \pm 8 \mathrm{ml}$ with a concentration of $475 \pm 200$ million spermatozoa $/ \mathrm{ml}$. The fractions contained $4.4 \pm 1.8$ billion spermatozoa per ejaculate. After collection, the initial motility of the spermatozoa was $65 \pm 10 \%$ and the post-thaw motility was $40 \pm 10 \%$, the relative motility being $65 \pm 20 \%$ (post-thaw motility/initial motility) (Table 2).

The total single-cycle pregnancy rate was $24 \%$ at Day 21 (excluding 3 embryonic losses between Days 15 and 21). The pregnancy results of the different stallions varied from $10 \%$ to $33 \%$ per cycle. The result from stallion A was lower than that of the other stallions, however, the difference was not statistically significant (Table 2). The doses from stallion A had varying dilution ratios, but since only 2 mares became pregnant, it seems obvious that the sperm from stallion A is not suitable for freezing. When the low results $(10 \%)$ of stallion $\mathrm{A}$ were excluded, the overall pregnancy rate per cycle was $31 \%$.

For the individual stallions, the distribution of the dilution ratios of the ejaculates, the number of the inseminations and the pregnant mares are shown in Fig. 1. Some inseminations were conducted using combined doses from the same stallion (dilution ratio could not be identified), and they were excluded from Fig. 1. One pregnancy was detected in the 7 inseminations with such doses.

Due to different dilution ratios, the amount of seminal plasma and also the concentration of the extender components varied between doses, but the glycerol concentration was constant. Most inseminations were done with 
Table 2. Motility and fertility results of the different stallions and the percentages of motile spermatozoa.

\begin{tabular}{|c|c|c|c|c|}
\hline Stallion & $\begin{array}{l}\text { Single-cycle } \\
\text { pregnancy rate } \\
\text { on day } 21(\%)\end{array}$ & $\begin{array}{l}\text { Initial } \\
\text { motility of } \\
\text { sperm (\%) }\end{array}$ & $\begin{array}{l}\text { Post-thaw } \\
\text { motility of } \\
\text { sperm (\%) }\end{array}$ & $\begin{array}{l}\text { Relative } \\
\text { motility of } \\
\text { sperm (\%) }\end{array}$ \\
\hline A & $2 / 21$ & $66 \pm 5$ & $49 \pm 15$ & $75 \pm 26$ \\
\hline B & $6 / 20^{a}$ & $63 \pm 5$ & $38 \pm 4$ & $60 \pm 8$ \\
\hline $\mathrm{C}$ & $6 / 18$ & $61 \pm 10$ & $49 \pm 9$ & $83 \pm 3$ \\
\hline D & $3 / 11^{\text {b }}$ & $68 \pm 5$ & $35 \pm 2$ & $53 \pm 6$ \\
\hline
\end{tabular}

$a=1$ and $b=2$ embryonic deaths (not included in pregnancy rates on day 21 ).

doses diluted more than 1 to 2 . Interestingly, when doses diluted less than $1: 2$ were used, the pregnancy rate was $36 \%(5 / 14)$ (Fig. 1$)$.

\section{Discussion}

In the commercial breeding program of EquiTechning in France, 33-36\% per cycle pregnancy results were achieved in the years 19891990 (Anon. 1991). Palmer (1984) has reported a $25 \%$ pregnancy result per cycle in an insemination trial and Julienne (1987) has reported $35 \%$ single cycle pregnancy rates with INRA-82 freezing method under stud farm conditions. In this study, the pregnancy rates of the 3 stallions were similar to those reported previously. This indicates that stallion semen can be diluted with the skim-milk extender without centrifugation. Because the timing of the inseminations after ovulation was different in our study and also the concentration of the seminal plasma varied in doses due to different dilution ratios, a direct comparison of our results with the previous reports is not possible. With frozen stallion semen, large differences have been found in fertility of individual stallions (Tischner 1979, Cochran et al. 1983, Cristanelli et al. 1984, Müller 1987). This could also be seen in our results, where the semen of stallion A showed low fertility.

The 2 first jets contain approximately $60 \%$ of all ejaculated spermatozoa and the 3 first jets about $80 \%$ (Tischner et al. 1974, Bittmar et al. 1992). This causes loss of spermatozoa in those cases, where only the first jet of the ejaculate is dense enough for dilution. In this study, we mostly collected the first or 2 first jets of the ejaculates in order to avoid the centrifugation step. Thus, only a small volume of concentrated semen was collected, which could be diluted more than $1: 2$. In some ejaculates, however, the initial volume of semen was larger with a low concentration of spermatozoa resulting in dilution ratios of only 1 : 1.1 - $1: 1.2$. Interestingly, when these doses were used in the inseminations, the fertility results were at least not worse than those with higher dilution ratios. Pickett et al. (1975) and Bittmar et al. (1992) observed a significant depression in post-thaw motility of spermatozoa at a dilution ratio of $1: 1$ and found that the dilution ratios of $1: 4-1: 8$ gave the highest post-thaw motilities. Their findings are, however, based on post-thaw motility results, not fertility results, and it is well-known that motility is not necessarily a good criterion for fertility. In doses diluted less than $1: 2$, the amount of egg yolk is reduced to about $1 \%$, and the concentrations of the other extender components are reduced nearly to one half. The constant concentration of glycerol was $2.5 \%$, which is low compared with the recommended glycerol concentrations (Cochran et 
al. 1984, Cristanelli et al. 1984). Nevertheless, the semen frozen in these doses retained its fertility indicating that the seminal plasma may contain components complementary to egg yolk (Jasko et al. 1992). However, it must be emphasized that only a few ejaculates were deep-frozen with the low dilution ratio, and further studies are needed to confirm these preliminary findings.

\section{Acknowledgments}

The authors wish to thank Mrs. Marja Miskala, Ms. Arja Mansala, Ms. Helena Mäkelä, Mr. Niilo Lyytikäinen, Ms. Tiina Riihimäki, and Ms. Virpi Vuori for excellent technical assistance and Dr. Mirja Huhtinen, Dr. Tiina Kotilainen, Dr. Helena Kuntsi, and Dr. Elina Kyynäräinen for their help during the insemination trials at the Equine Research Station. This work was supported in part by grants from the Research Council for Agricultural Sciences, the Academy of Finland.

\section{References}

Anonymous: Equi-Techning: Le Cataloque des Elites, Equi-Techning, Service Commercial, Haras de la Cour-Bonnet 14700 Falaise-France, 1991.

Bittmar A, Kosiniak K, Podstawaski Z: Association between stallion age, sperm concentration and semen fertility. 12th Int. Congr. Animal Reprod. The Hague, The Netherlands, Congr. Proc. 1992, 4, 1393-1395.

Brinsko SP, Varner DD: Artificial insemination and preservation of semen. Stallion Management, Veterinary Clinics of North America. Equine Practice 1992, 8, 1205-218.

Cochran JD, Amann RP, Squires EL, Pickett BW: Fertility of frozen thawed stallion semen extended in lactose-EDTA- egg yolk extender and packaged in $1.0 \mathrm{ml}$ straws. Theriogenology 1983 , 20, 735-741.

Cochran JD, Amann RP, Froman DP, Pickett BW: Effects of centrifugation, glycerol level, cooling to $5^{\circ} \mathrm{C}$, freezing rate and thawing rate on the post thaw motility of equine sperm. Theriogenology 1984, 22, 25-38.

Conover WJ: Practical Nonparametric Statistics, 2nd edition. John Wiley \& Sons, New York, 1980.
Cristanelli MJ, Squires RP, Amann RP, Pickett BW: Fertility of stallion semen processed, frozen and thawed by a new procedure. Theriogenology 1984, 22, 39-45.

Darenius K, Darenius A: Fertility data in the horse and the occurrence of pregnancy and neonatal loss in relation to breeding method. 12th Int. Congr. Animal Reprod. The Hague, The Netherlands, Congr. Proc. 1992, 4, 1859-1860.

Jasko DJ, Moran DM, Farlin ME, Squires EL: Effect of seminal plasma dilution or removal on spermatozoal motion characteristics of cooled stallion semen. Theriogenology 1991, 35, 1059-1067.

Jasko DJ, Hathaway JA, Schaltenbrand VL, Simper $W D$, Squires $E L$ : Effect of seminal plasma and egg yolk on motion characteristics of cooled stallion spermatozoa. Theriogenology 1992, 37, 1241-1252.

Julienne $P$ : Insémination artificielle en sperme frais avec étalons troutters francais et en sperme conglé avec étalons de Selle francais dans un haras. Farm. 13eme journee de la recherche chevalie'ne, Paris, 1987, 12, 44-55.

Koskinen E, Lindeberg H, Kuntsi H, Ruotsalainen L, Katila T: Fertility of mares after postovulatory insemination. J. Vet. Med. A. 1990, 37, 77-80.

Martin JC, Klug E, Günzel A-R: Centrifugation of stallion semen and its storage in large volume straws. J. Reprod. Fert., Suppl. 1979, 27, 47-51.

Müller Z: Practicalities of insemination of mares with deep-frozen semen. J. Reprod. Fert., Suppl. 1987, 35, 121-125.

Palmer E: Factors affecting semen survival and fertility. 10th Int. Congr. Anim. Reprod. \& A. I., Urbana-Champaign, Congr. Proc. 1984, 3, 377 379.

Pickett BW, Sullivan JJ, Byers MS, Pace MM, Remmenga $E E$ : Effect of centrifugation and seminal plasma on motility and fertility of stallion and bull spermatozoa. Fertil. Steril. 1975, 26, 67-174.

Tischner M, Kosiniak K, Bielanski W: Analysis of the pattern of ejaculation in stallions. J. Reprod. Fert. 1974, 41, 329-335.

Tischner M: Evaluation of deep-frozen semen in stallions. J. Reprod. Fert., Suppl. 1979, 27, 53-59.

Volkmann DH, van Zyl D: Fertility of stallion semen frozen in $0.5 \mathrm{ml}$ straws. J. Reprod. Fert., Suppl. 1987, 35, 143-148.

Woods J, Bergfelt D R, Ginther O J: Effects of time . of insemination relative to ovulation on pregnancy rate and embryonic-loss rate in mares. Equine vet. J. 1990, 22, 410-415. 


\section{Sammanfattning}

Spermiernas frysbarhet och dräktighetsresultat med ocentrifugerad hingstsperma

Sammanlagt 19 ejakulat samlades från 4 hingstar med öppen vagina. Totalvolymen av de 1, 2 eller 3 första spermierika fraktionerna var $12 \pm 8 \mathrm{ml}$ och koncentrationen $475 \pm 200$ milj. spermier/ml. Sperman späddes genast efter uppsamlingen med mjölkbaserad spädningsvätska och djupfrystes. Totalantalet spermier i de 7-9 ml inseminationsdoserna var
0.7 till 1 miljard och koncentrationen 100 milj. spermier/ml. Spädningsgraden varierade mellan 1:1 - 1:8 (sperma : spädningsvätska). Vid en follikelstorlek på $35 \mathrm{~mm}$, kontrollerades stona 2 gånger dagligen både med palpation och ultraljud. Senast 12 timmar efter ovulationen inseminerades 48 ston under sammanlagt 70 brunster. Dräktighetsresultatet ( $21 \mathrm{~d}$ ) var $24 \%$ per inseminerad brunst. Mellan hingstarna varierade resultatet från $10 \%$ till $33 \%$.

(Received April 26, 1994; accepted August 19, 1994).

Reprints may be requested from: Dr. M.-L. Heiskanen, Department of Biochemistry \& Biotechnology, University of Kuopio, P.O. Box 1627, SF-70211 Kuopio, Finland. 